\title{
Angiotensin II-induced Hypertrophy of Cultured Murine Proximal Tubular Cells Is Mediated by Endogenous Transforming Growth Factor- $\beta$
}

\author{
Gunter Wolf, Elfriede Mueller, Rolf A. K. Stahl, and Fuad N. Ziyadeh * \\ Division of Nephrology, Department of Medicine, University of Frankfurt, D-6000 Frankfurt am Main 70, Germany; \\ and *the Penn Center for the Molecular Study of Kidney Diseases, Renal-Electrolyte Division of the \\ Department of Medicine, University of Pennsylvania, Philadelphia, Pennsylvania 19104
}

\begin{abstract}
Previous studies by our group have demonstrated that angiotensin II (ANG II), as a single factor in serum-free medium, induces cellular hypertrophy of a cultured murine proximal tubular cell line (MCT). The present study was performed to test the hypothesis that this growth effect was mediated by activation of endogenous transforming growth factor- $\beta$ (TGF- $\beta$ ). Exogenous TGF- $\beta_{1}(1 \mathrm{ng} / \mathrm{ml})$ mimicked the growth effects observed with $10^{-8} \mathrm{M}$ ANG II (inhibition of DNA synthesis and induction of cellular hypertrophy). A neutralizing anti-TGF- $\beta$ antibody attenuated the ANG II-induced increase in de novo protein and total RNA synthesis as well as total protein content. This antibody also abolished the ANG II-mediated inhibition of $\left[{ }^{3} \mathbf{H}\right]$ thymidine incorporation into quiescent $\mathrm{MCT}$ cells. Control IgG or an unrelated antibody had no effect. A bioassay for TGF- $\beta$ using mink lung epithelial cells revealed that MCT cells treated with ANG II released active TGF- $\beta$ into the cell culture supernatant. Northern blot analysis and semi-quantitative cDNA amplification demonstrated increases in steadystate levels for TGF- $\beta_{1}$ mRNA after ANG II stimulation of MCT cells, but not in a syngeneic murine mesangial cell line. Our data indicate that the ANG II-induced hypertrophy in MCT cells is mediated by synthesis and activation of endogenous TGF- $\beta$. It is intriguing to speculate that TGF- $\beta$ may play a role in the early tubular cell hypertrophy and the subsequent interstitial scarring observed in several models of chronic renal injury that are characterized by increased activity of intrarenal ANG II. (J. Clin. Invest. 1993. 92:1366-1372.) Key words: angiotensin II • TGF- $\beta$ - hypertrophy $\bullet$ MCT cells • kidney growth $\bullet$ proliferation
\end{abstract}

\section{Introduction}

Adaptive renal growth plays a major role in the progression of renal disease (1). Chronic injury of the nephron results often in compensatory hypertrophy of the remnant kidney structures $(2,3)$. Although all the structural constituents of the nephron are involved in such growth responses, enlargement of proximal tubular cells principally accounts, in quantitative terms,

Address correspondence to Dr. Gunter Wolf, Division of Nephrology, Department of Medicine, University of Hamburg, Martinishße 52, 20251 Hamburg, Germany.

Received for publication 15 January 1993 and in revised form 19 April 1993.

J. Clin. Invest.

(c) The American Society for Clinical Investigation, Inc.

0021-9738/93/09/1366/08 \$2.00

Volume 92, September 1993, 1366-1372 for the predominant component of compensatory hypertrophy (2). The mechanisms inducing tubulo-epithelial cell hypertrophy are incompletely understood, and fundamental differences in the cell biology of this growth response as opposed to cellular hyperplasia (which occurs after acute tubular necrosis) have been sorted out $(3,4)$. Although many investigators have tried to isolate and characterize putative humoral factors that may mediate hypertrophy, the so-called renotropins $(5,6)$, the majority of these factors also induce cellular proliferation of cultured tubular cells $(3,7)$. Only a few factors are hypertrophogenic for tubular cells in vitro. Such effectors are transforming growth factor- $\beta$ (TGF- $\left.\beta ;{ }^{1} 8\right)$, high glucose content of the culture medium $(9,10)$, insulin-like growth factor $1(11)$, and angiotensin II (ANG II; 12-16). We (12-15) and others (16) have investigated in a series of experiments the effects on ANG II in cultured proximal tubular cells. This peptide induces hypertrophy of tubular cells as defined by increases in cellular size, protein synthesis, protein and RNA content, but not in DNA synthesis in MCT cells (a murine proximal tubular cell line; 12), and LLC-PK ${ }_{1}$ cells (a porcine cell line that exhibits properties of proximal tubules; 15). In contrast to the hypertrophic action of ANG II, the peptide inhibited cellular proliferation as measured by thymidine incorporation $(12,15)$.

The present study was undertaken to evaluate whether the hypertrophogenic effects of ANG II on MCT cells are mediated by an increase in synthesis and/or activation of endogenous TGF- $\beta$. This ubiquitous growth factor functions in an autocrine or paracrine mode to elicit a multiplicity of cellular effects including inhibition of cellular proliferation and induction of tubuloepithelial cell hypertrophy (8). Our studies demonstrate that ANG II stimulates in MCT cells the production of active TGF- $\beta$ as assessed by a bioassay using mink lung epithelial cells. Furthermore, expression of steady-state mRNA levels for TGF- $\beta$ in MCT cells is stimulated by ANG II. In addition, studies applying a neutralizing anti-TGF- $\beta$ antibody collectively demonstrate that the ANG II-induced growth effects in MCT cells are mediated by bioactivation of endogenous TGF- $\beta$.

\section{Methods}

Cell culture. MCT cells are a proximal tubular cell line isolated from 8-10-wk-old naive SJL/J (H-2 $)$ mice (17). They have been propa-

1. Abbreviations used in this paper: $\mathrm{ANG}$, angiotensin; dNTP, deoxynucleotide triphosphate; GAPDH, glyceraldehyde-3-phosphate dehydrogenase; MCT, murine proximal tubular cell line; MMC, murine mesangial cells; PCR, polymerase chain reaction; PDGF, platelet-derived growth factor; TGF- $\beta$, transforming growth factor- $\beta$; VSMC, vascular smooth muscle cells. 
gated in culture by transformation with nonreplicating, non-capsidforming SV-40 virus (17). We $(9,10,12-14,18)$ and other groups ( 19 , 20) have extensively characterized this cell line. MCT cells exhibit many characteristics of proximal tubular cells including positive staining for alkaline phosphatase and cytokeratin (17) and expression of the nephritogenic tubular antigen and brush border villi (17). Furthermore, these cells possess ANG II (12) and parathormone receptors (13), high-affinity binding sites for epidermal growth factor (17), a sodium-hydrogen exchanger $(12,19)$, and a sodium-phosphate transport system (20). For the current studies, MCT cells were cultured as a differentiated cell line in DME (450 mg/dl glucose) with $100 \mathrm{U} / \mathrm{ml}$ penicillin, $100 \mu \mathrm{g} / \mathrm{ml}$ streptomycin, $2 \mathrm{mM}$ supplemental glutamine, and $10 \%$ heat-inactivated fetal calf serum (Gibco, Eggenstein, Germany) at $37^{\circ} \mathrm{C}$ in $5 \% \mathrm{CO}_{2}$. Cells were passaged every $72-96 \mathrm{~h}$ by light trypsinization.

Measurement of cellular proliferation. The incorporation of $\left[{ }^{3} \mathrm{H}\right]-$ thymidine into DNA was used as one sensitive measurement of cellular proliferation $(9,12,21) \cdot 10^{4} \mathrm{MCT}$ cells were transferred into each well of a 96-well plastic cell culture plate (Nunc, Roskilde, Denmark) and rested in serum-free DME for $24 \mathrm{~h}$. Subconfluent, quiescent cells were stimulated for $48 \mathrm{~h}$ with two doses (every $24 \mathrm{~h}$ ) of $10^{-8} \mathrm{M}$ ANG II acetate salt (Sigma, Deisenhofen, Germany) dissolved in culture medium. We have previously demonstrated that this dose of ANG II induced cellular hypertrophy in MCT cells associated with an inhibition of $\left[{ }^{3} \mathrm{H}\right]$ thymidine incorporation ( 12 ). In some wells, $30 \mu \mathrm{g} / \mathrm{ml}$ neutralizing rabbit anti-porcine TGF- $\beta$ antibody (IgG fraction; binds to the active form of both TGF- $\beta_{1}$ and TGF- $\beta_{2} ;$ R \& D Systems, Minneapolis, $\mathrm{MN}$ ) was included. Other wells received the same concentration of normal rabbit IgG (Sigma). In addition, MCT cells were also treated with a single dose of $1 \mathrm{ng} / \mathrm{ml}$ recombinant human TGF- $\beta_{1}(R \& D)$. Cells were pulsed with $1 \mu \mathrm{Ci}$ per well $\left[{ }^{3} \mathrm{H}\right]$ thymidine $(5 \mathrm{Ci} / \mathrm{mmol}$; New England Nuclear, Dreieich, Germany) during the last $6 \mathrm{~h}$ of culture. After pulsing, cells were subsequently washed twice in PBS, incubated for $10 \mathrm{~min}$ at $37^{\circ} \mathrm{C}$ with $200 \mu \mathrm{l}$ of trypsin/EDTA, and harvested on glass-filter paper with an automated cell harvester. Radioactivity was measured by liquid scintillation spectroscopy. Data were pooled from four independent experiments with four replicates in each. In additional experiments, $10^{6} \mathrm{MCT}$ cells were plated in each well of a six-well plate (Nunc), rested for $24 \mathrm{~h}$, and stimulated as described above. After the incubation period, cells were trypsinized, scraped off the plate, and counted in a Fuchs-Rosenthal hemocytometer.

De novo protein synthesis and total protein content. In accordance with our previous investigations, incorporation of $\left[{ }^{3} \mathrm{H}\right]$ leucine into acid-precipitable proteins was used as a sensitive parameter for measuring de novo protein synthesis $(9,12,13,21)$. MCT cells $\left(5 \times 10^{5}\right.$ per well) were plated in 24-well plates (Nunc), rested in serum-free medium for $48 \mathrm{~h}$, and then stimulated for $48 \mathrm{~h}$ as appropriate. For the last $12 \mathrm{~h}$, cells were pulsed with $5 \mu \mathrm{Ci}\left[{ }^{3} \mathrm{H}\right.$ ]leucine ( $142 \mathrm{Ci} / \mathrm{mmol}$; Amersham, Braunschweig, Germany). Same cells were also treated with 1 $\mathrm{ng} / \mathrm{ml}$ recombinant human TGF- $\beta_{1}$ in the presence or absence of $30 \mu \mathrm{g}$ rabbit anti-porcine TGF- $\beta$ antibody. The cells were then washed three times in ice-cold PBS, and proteins were precipitated with $10 \%$ TCA. Proteins were subsequently redissolved in $0.5 \mathrm{M} \mathrm{NaOH}$ plus $0.1 \%$ Triton X-100 and counted in $3 \mathrm{ml}$ Rotiszint scintillation cocktail (Roth, Karlsruhe, Germany). Data were pooled from six separate experiments with two to three replicates in each. Cells incubated with control medium were assigned a relative value for $\left[{ }^{3} \mathrm{H}\right]$ leucine incorporation of $100 \%$; incorporation into MCT cells treated with mediators was calculated as percent of control.

For measurement of total protein content, $10^{6}$ cells were plated in six-well plates, made quiescent for $24 \mathrm{~h}$, and then stimulated for $48 \mathrm{~h}$ as described above. Cells were harvested with $0.05 \%$ EDTA, counted, and lysed in $100 \mu 12 \mathrm{M} \mathrm{NaOH}$, and total protein was measured by a modification of the Lowry method using bovine serum albumin as a standard (12). Protein content is expressed as micrograms protein per $10^{6}$ cells.

$\left[{ }^{3} \mathrm{H}\right]$ Uridine incorporation into $R N A$. Incorporation of $\left[{ }^{3} \mathrm{H}\right]$ uridine was used as a measurement of total RNA synthesis. $5 \times 10^{4}$ cells were plated per well of a 24-well plate, rested in serum-free DME for $24 \mathrm{~h}$, and stimulated for another $48 \mathrm{~h}$ with daily doses (every $24 \mathrm{~h}$ ) of $10^{-8} \mathrm{M}$ ANG II. $30 \mu \mathrm{g} / \mathrm{ml}$ of the neutralizing anti-TGF- $\beta$ antibody was included in some wells. Other wells were treated in parallel for $48 \mathrm{~h}$ with a single dose of $1 \mathrm{ng} / \mathrm{ml}$ recombinant human TGF- $\beta_{1}$. All cells were incubated for the last $24 \mathrm{~h}$ with $1 \mu \mathrm{Ci}\left[{ }^{3} \mathrm{H}\right]$ uridine $(30-50 \mathrm{mmol} /$ $\mathrm{Ci}$; Amersham). At the end of the culture period, cells were washed four times with ice-cold PBS, lysed in $0.5 \mathrm{M} \mathrm{NaOH}$, and counted for radioactivity.

Bioassay for $T G F-\beta_{1}$. Inhibition of $\left[{ }^{3} \mathrm{H}\right]$ thymidine incorporation into DNA of CCL-64 mink lung epithelial cells was used as a sensitive bioassay for TGF- $\beta(22,23)$. CCL-64 cells were obtained from the American Type Culture Collection (Rockville, MD) and were seeded at a concentration of $10^{4}$ cells per well of a 96-well plate in DME with $10 \%$ fetal calf serum. After $24 \mathrm{~h}$, the medium was changed to serumfree DME for another $24 \mathrm{~h}$. CCL-64 cells were then incubated for an additional $24 \mathrm{~h}$ with MCT-conditioned medium in defined serum-free DME (see below). Cells were pulsed for the last $6 \mathrm{~h}$, harvested, and processed as described above. To test for the specificity of the growth response, $30 \mu \mathrm{g} / \mathrm{ml}$ of neutralizing anti-TGF- $\beta$ antibody or $100 \mu \mathrm{g} / \mathrm{ml}$ goat anti-human platelet-derived growth factor B-neutralizing antiserum (Collaborative Research, Bedford, MA) were included in conditioned medium derived from ANG II-stimulated MCT cells. Control CCL-64 cells were treated directly with either serum-free DME, medium supplemented with $10^{-8} \mathrm{M}$ ANG II, or different concentrations of recombinant human TGF- $\beta_{1}(10$ and $30 \mathrm{pg} / \mathrm{ml})$ in the presence or absence of $30 \mu \mathrm{g} / \mathrm{ml}$ neutralizing anti-TGF- $\beta$ antibody.

Conditioned medium was obtained from quiescent MCT cells, grown in 24-well plates $\left(5 \times 10^{5}\right.$ cells originally plated per well) for $24-48 \mathrm{~h}$ in either control medium, or in the presence of $10^{-8}-10^{-6} \mathrm{M}$ ANG II. ANG II was given daily for $48 \mathrm{~h}$ to cells stimulated with the peptide. Furthermore, MCT cells were also incubated with $10^{-6} \mathrm{M}$ of the specific AT, -receptor blocker DuP 753 (Iosartan; gift of Dr. R. D. Smith, Du Pont-Merck, Sharp \& Dohme, Wilmington, DE) in the presence or absence of ANG II. To detect bioactive TGF- $\beta$ that is released by MCT cells, conditioned medium was directly added to CCL-64 cells without prior heat or acid activation. $\left[{ }^{3} \mathrm{H}\right]$ Thymidine incorporation into CCL-64 cells incubated with conditioned medium obtained from MCT cells grown in control medium (no ANG II) was assigned a relative value of $100 \%$. Bioassay studies were repeated four times with six replicates from each independent stimulation experiment.

Northern blot analysis. MCT cells were rested for $24 \mathrm{~h}$ in serum-free medium and incubated for $6,12,24$, and $48 \mathrm{~h}$ with $10^{-8} \mathrm{M}$ ANG II. ANG II was given two times (every $24 \mathrm{~h}$ ) to cells stimulated for a total of $48 \mathrm{~h}$. To control for cell type specificity, syngeneic murine mesangial cells (MMC; 24 ) were also treated with $10^{-8}$ M ANG II for $48 \mathrm{~h}$. Cells were washed twice in ice-cold RNAse-free PBS and then were lysed in 4 $\mathrm{M}$ guanidinium isothiocyanate, $25 \mathrm{mM}$ sodium citrate, $\mathrm{pH} \mathrm{7,0.5 \%}$ sarcosyl, and $0.1 \mathrm{M}$ 2-mecaptoethanol. Total RNA was isolated by repeated phenol-chloroform extractions and isopropanol precipitations as described by Chomczynski and Sacchi (25).

Total RNA ( $20 \mu \mathrm{g}$ per lane) was denatured by heating in formamide/formaldehyde at $65^{\circ} \mathrm{C}$ for $20 \mathrm{~min}$ and was electrophoresed through a $1.2 \%$ agarose gel containing $2.2 \mathrm{M}$ formaldehyde. A RNAladder (Gibco BRL, ) was used to determine the size of transcripts. The RNA was then vacuum blotted to a nylon membrane (Zetabind, Cuno Laboratory Products, Meriden, CT), and crosslinked with UV shortwave. All hybridizations were carried out in a rotating drum in a temperature-controlled oven. The membranes were prehybridized at $42^{\circ} \mathrm{C}$ for $24 \mathrm{~h}$ in $5 \times$ SSPE ( $20 \times$ SSPE: $3 \mathrm{M} \mathrm{NaCl}, 0.2 \mathrm{M} \mathrm{NaH}_{2} \mathrm{PO}_{4}, 0.02 \mathrm{M}$ EDTA), $5 \times$ Denhardt's solution ( $50 \times$ Denhardt's: $1 \%$ Ficoll, $1 \%$ polyvinylpyrrolidone, $1 \%$ bovine serum albumin, $50 \%$ formamide, $0.1 \%$ SDS), and $0.1 \mathrm{mg} / \mathrm{ml}$ denatured salmon sperm DNA. cDNA inserts were separated from their vectors in low-melt agarose and labeled with $5 \mu \mathrm{Ci} \mathrm{[}{ }^{32} \mathrm{P}$ ]deoxyadenosine 5 'triphosphate $(3,000 \mathrm{Ci} / \mathrm{mmol}$; New England Nuclear) using hexanucleotide primers $(26)$. The probes used were an EcoRI fragment encoding the human TGF- $\beta_{1}$ gene (27; gift of Dr. A. Singh, Genentech, San Francisco, CA) and a PstI frag- 
ment encoding the rat glyceraldehyde-3-phosphate dehydrogenase (GAPDH; 28). The labeled fragments were separated from unincorporated nucleotides by Sephadex G-25 chromatography. Blots were hybridized for $24 \mathrm{~h}$ in the same buffer as used for prehybridization with $10^{6} \mathrm{cpm} / \mathrm{ml}$ probe at $42^{\circ} \mathrm{C}$. The membranes were washed twice for 45 min in $2 \times$ SSC ( $20 \times$ SSC: $3 \mathrm{M} \mathrm{NaCl}, 0.3 \mathrm{M}$ sodium citrate, $\mathrm{pH} 7.0)$ and $0.5 \% \mathrm{SDS}$ at $65^{\circ} \mathrm{C}$. Autoradiography was performed with intensifying screens at $-70^{\circ} \mathrm{C}$ for 3-4 d. Blots were stripped in $5 \mathrm{mM}$ Tris$\mathrm{HCl}, 0.2 \mathrm{mM}$ EDTA, $0.5 \%$ sodium pyrophosphate, and $5 \times$ Denhardt's solution for $3 \mathrm{~h}$ at $65^{\circ} \mathrm{C}$ and subsequently were rehybridized with a cDNA probe for GAPDH to account for small loading and transfer variations. Exposed films were scanned with a laser densitometer (GS 300; Hoefer Scientific Instruments, San Francisco, CA), and the area under the curve was determined by Gaussian integration with the computer program GS $365 \mathrm{~W}$ (Hoefer Scientific Instruments). Relative RNA levels were calculated as described (12), assigning the hybridization signal in control lanes a relative value of one. All Northern blots were repeated twice.

Semi-quantitative cDNA amplification. To corroborate the stimulation of TGF- $\beta_{1}$ mRNA by ANG II, we used semi-quantitative cDNA amplification as a sensitive method to assess the level of TGF- $\beta_{1}$ transcripts and the time-course of the ANG II-induced stimulation (29, 30). cDNA was synthesized from $10 \mu \mathrm{g}$ of total RNA using $0.7 \mu \mathrm{g}$ of poly-d(T) primer (Pharmacia-LKB, Freiburg, Germany) with $500 \mathrm{U}$ of Moloney murine leukemia virus reverse transcriptase diluted in 50 $\mu$ l of buffer containing $50 \mathrm{mM}$ Tris- $\mathrm{HCl}$ ( $\mathrm{pH} 8.39,75 \mathrm{mM} \mathrm{KCl}, 3 \mathrm{mM}$ $\mathrm{MgCl}_{2}, 10 \mathrm{mM}$ dithiothreitol, and $500 \mu \mathrm{M}$ dNTPs). cDNAs were precipitated with $7.5 \mathrm{M}$ ammonium acetate and isopropanol, were spun, washed twice in $70 \%$ ethanol, air dried, and were resuspended in distilled water, and the concentration of CDNA was determined by UV absorbance at $260 \mathrm{~nm}$.

Polymerase chain reactions (PCR) for semi-quantitative comparisons of TGF- $\beta_{1}$ transcripts were normalized for the presence of GAPDH as previously described (29-31). We used $500 \mathrm{ng}$ cDNA for each PCR reaction. A total of $150 \mathrm{ng}$ of each of the following primers was used: mouse TGF- $\beta_{1}$ (32; sense: 5'CTCCCACTCCCGTGGCTTCTAG3', antisense: 5'GTTCCACATGTTGCTCCACACTTG3'), rat GAPDH (28; sense: 5'AATGCATCCTGCACCACCAA3'; antisense: 5'GTAGCCATATTCATTGTCATA3'). The mouse TGF- $\beta_{1}$ primers comprise the $389-860$-bp stretch of the murine TGF- $\beta_{1}$ gene resulting in an amplification product of $471 \mathrm{bp}$ (32). The size of the GAPDH product is $512 \mathrm{bp}$. The GeneAMP kit (Perkin Elmer Cetus, Ueberlingen, Germany) was used for all amplification reactions. Reactions were performed exactly as described before $(29,30)$ with $200 \mu \mathrm{M}$ of each

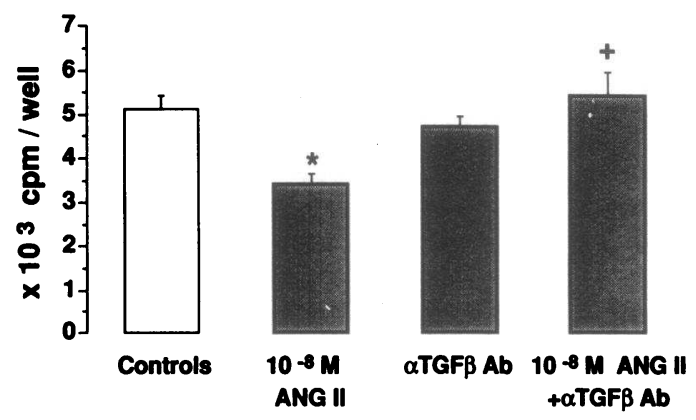

Figure 1. $\left[{ }^{3} \mathrm{H}\right]$ Thymidine incorporation into MCT cells. Cells were stimulated for $48 \mathrm{~h}$ with two doses (every $24 \mathrm{~h}$ ) of $10^{-8} \mathrm{M}$ ANG II. Additional cells were incubated with ANG II in the presence of 30 $\mu \mathrm{g} / \mathrm{ml}$ neutralizing anti-TGF- $\beta$ antibody ( $\alpha$ TGF $\beta$ Ab). ANG II alone induced a significant decrease in $\left[{ }^{3} \mathrm{H}\right]$ thymidine incorporation compared with cells incubated in medium without ANG II (controls). This decrease in proliferation was abolished by the neutralizing anti-TGF- $\beta$ antibody whereas the antibody had no significant effect in the absence of ANG II. $n=12,{ }^{*} P<0.05$ vs. unstimulated control cells; ${ }^{+} P<0.05$ vs. cells treated with ANG II only.
dNTP and $2.5 \mathrm{U}$ of Taq polymerase in the supplied amplification buffer ( $20 \mathrm{mM}$ Tris- $\mathrm{HCl}, \mathrm{pH} \mathrm{8.3,25 \textrm {mM } \mathrm { KCl } , 2 . 0 \mathrm { mM } \mathrm { MgCl }}$, and $0.05 \%$ Tween 20 ). 40 cycles with an annealing temperature of $55^{\circ} \mathrm{C}$ for $1.5 \mathrm{~min}$, an extension step at $72^{\circ} \mathrm{C}$ for $2 \mathrm{~min}$, and a denaturing temperature of $92^{\circ} \mathrm{C}$ for $1 \mathrm{~min}$ were performed. Identity of amplification products was established by Southern hybridization using end-labeled internal oligonucleotides (data not shown). Moreover, amplification of a control plasmid (Clontech, Palo Alto, CA) with the TGF- $\beta_{1}$ primers resulted in a product of $471 \mathrm{bp} .15 \mu \mathrm{l}$ of each reaction product was then separated in a $1.9 \%$ agarose gel containing $0.5 \mu \mathrm{g} / \mathrm{ml}$ of ethidium bromide. Gels were photographed with Polaroid 55 negative film, and the reaction products on the negative film were scanned by densitometry. A normalization quotient between TGF- $\beta_{1}$ and GAPDH was calculated as described previously (29-31). Each replicate represents a separate cell stimulation experiment and amplification reaction.

Statistical analysis. All data are presented as the means \pm SEM. For multiple comparisons, the nonparametric Kruskal-Wallis test for multiple sample comparison was used first. The statistical significance between individual groups was tested by the Wilcoxon-Mann-Whitney test. $P$ values $<0.05$ were considered significant.

\section{Results}

Proliferation studies. We have previously demonstrated that ANG II does not stimulate cellular proliferation in MCT and LLC-PK ${ }_{1}$ cells $(12,15)$. Rather, $10^{-8} \mathrm{M}$ of the peptide inhibited $\left[{ }^{3} \mathrm{H}\right]$ thymidine incorporation into DNA compared with control medium $(12,15)$. Since TGF- $\beta$ is a well-known inhibitor of cellular proliferation in epithelial cells including MCT cells $(10,33)$, we wondered whether ANG II-induced endogenous production of TGF- $\beta$ may be responsible for this inhibition of mitogenesis. Fig. 1 demonstrates that treatment with $10^{-8} \mathrm{M}$ ANG II for $48 \mathrm{~h}$ significantly inhibited $\left[{ }^{3} \mathrm{H}\right]$ thymidine incorporation into DNA of MCT cells. However, coincubation of cells with $10^{-8} \mathrm{M}$ ANG II and $30 \mu \mathrm{g} / \mathrm{ml}$ of a neutralizing anti-TFG- $\beta$ antibody totally attenuated this inhibition of mitogenesis. The same concentration of anti-TGF- $\beta$ antibody had no significant effect on baseline proliferation of cells treated for $48 \mathrm{~h}$ with control medium. $30 \mu \mathrm{g} / \mathrm{ml}$ of normal rabbit IgG had no significant effect on the ANG II-mediated suppression of proliferation $\left(10^{-8} \mathrm{M}\right.$ ANG II $+30 \mu \mathrm{g} / \mathrm{ml}$ normal rabbit IgG: $4.0 \pm 0.8 \times 10^{3} \mathrm{cpm}$ per well, $P<0.01$ vs. control cells: $5.0 \pm 0.4 \times 10^{3} \mathrm{cpm}$ per well, $n=5$ ). Exogenous recombinant human TGF- $\beta_{1}(1 \mathrm{ng} / \mathrm{ml})$ also markedly inhibited mitogenesis (TGF- $\beta_{1}: 3.2 \pm 0.2 \times 10^{3} \mathrm{cpm}$ per well, $P$ $<0.05$ vs. unstimulated control cells, $n=8$ ). We have previously confirmed that this antimitogenic effect of TGF- $\beta_{1}$ on MCT cells was blocked by the neutralizing anti-TGF- $\beta$ antibody (10). Table I reveals that cell counts decreased signifi-

Table I. Cell Number after 48 h of Incubation

\begin{tabular}{lc}
\hline & Cell number \\
\hline & $\times 10^{6}$ \\
Controls & $1.7 \pm 0.1$ \\
$10^{-8} \mathrm{M}$ ANG II & $1.6 \pm 0.2$ \\
Controls $+30 \mu \mathrm{g} / \mathrm{ml}$ anti-TGF- $\beta$ antibody & $1.5 \pm 0.1$ \\
$10^{-8} \mathrm{M}$ ANG II $+30 \mu \mathrm{g} / \mathrm{ml}$ anti-TGF- $\beta$ antibody & $2.0 \pm 0.1$ \\
$1 \mathrm{ng} / \mathrm{ml}$ recombinant human TGF- $\beta_{1}$ & $1.2 \pm 0.08^{*}$
\end{tabular}

Values are mean $\pm \mathrm{SEM} ; n=6 ;{ }^{*} P<0.05$ vs. controls. 
cantly only in the presence of $1 \mathrm{ng} / \mathrm{ml}$ exogenous TGF- $\beta_{1}$, but not in cells treated with $10^{-8} \mathrm{M}$ ANG II for $48 \mathrm{~h}$.

Total cellular protein and de novo protein synthesis. In contrast to the inhibition of DNA synthesis, daily doses of $10^{-8} \mathrm{M}$ ANG II for $48 \mathrm{~h}$ significantly stimulated de novo protein synthesis and total protein content in MCT cells (12-14). As demonstrated in Fig. 2, treatment of quiescent cells with ANG II resulted in a significant increase in total cellular protein content as determined by a modified Lowry method. The neutralizing anti-TGF- $\beta$ antibody ( $30 \mu \mathrm{g} / \mathrm{ml})$ abolished this stimulation whereas the antibody had no significant effect on cells incubated in control medium (DEME without serum) for $48 \mathrm{~h}$. Treatment with a single dose of $1 \mathrm{ng} / \mathrm{ml}$ recombinant human TGF $-\beta_{1}$ for $48 \mathrm{~h}$ also stimulated total protein content in MCT cells $\left(1 \mathrm{ng} / \mathrm{ml} \mathrm{TGF}-\beta_{1}: 217 \pm 21 \mu \mathrm{g}\right.$ protein $/ 10^{6}$ cells, $n=4, P$ $<0.05$ vs. unstimulated control cells: $156 \pm 12 \mu \mathrm{g}$ protein $/ 10^{6}$ cells). Table II shows the summary of the studies on the incorporation of $\left[{ }^{3} \mathrm{H}\right]$ leucine in TCA-precipitable de novo synthesized proteins. Counts obtained from control cells were assigned a value of $100 \%$. Stimulation of MCT cells with $10^{-8} \mathrm{M}$ ANG II for $48 \mathrm{~h}$ resulted in an $80 \%$ increase in $\left[{ }^{3} \mathrm{H}\right]$ leucine incorporation. A similar stimulation of protein synthesis was observed with a single dose of $1 \mathrm{ng} / \mathrm{ml}$ TGF $-\beta_{1}$. The ANG II-mediated increase in de novo protein synthesis was almost totally abolished by cotreatment with the neutralizing antiTGF- $\beta$ antibody. Moreover, we confirmed again that the used anti-TGF- $\beta$ antibody has indeed neutralizing activity against TGF- $\beta$ by performing TGF- $\beta$-stimulated $\left[{ }^{3} \mathrm{H}\right.$ ]leucine incorporation into MCT cells in the presence and absence of $30 \mu \mathrm{g} / \mathrm{ml}$ neutralizing anti-TGF- $\beta$ antibody (control: $1.35 \pm 0.15,1 \mathrm{ng} /$ ml TGF- $\beta_{1}: 2.79 \pm 0.52,{ }^{*}$ control plus anti-TGF- $\beta$ antibody: $1.54 \pm 0.22,1 \mathrm{ng} / \mathrm{ml}$ TGF- $\beta_{1}$ plus anti-TGF- $\beta$ antibody: $1.67 \pm 0.33 \times 10^{4} \mathrm{cpm} ; n=6,{ }^{*} P<0.01$ vs. control).

Total RNA synthesis. Since cellular hypertrophy is characterized not only by increases in protein synthesis and protein content but also by a stimulation of RNA synthesis in the absence of mitosis, total RNA synthesis was assessed by incorporation of $\left[{ }^{3} \mathrm{H}\right]$ uridine into de novo synthesized total RNA. As shown in Table III, $10^{-8} \mathrm{M}$ ANG II as well as recombinant TGF- $\beta_{1}$ significantly stimulated $\left[{ }^{3} \mathrm{H}\right]$ uridine incorporation into RNA. The ANG II-mediated increase in RNA synthesis

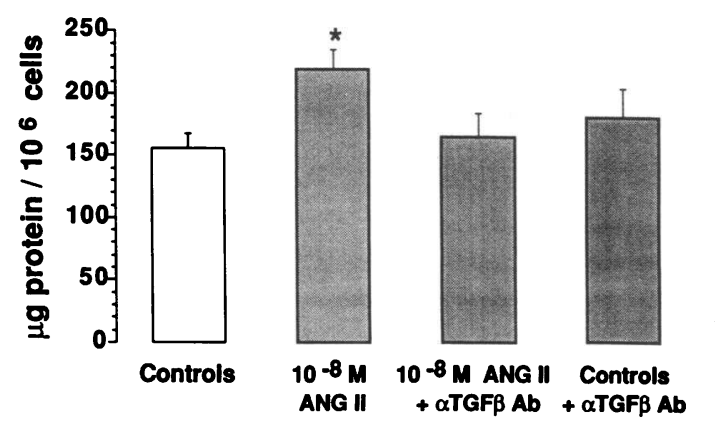

Figure 2. Total protein content in MCT cells as determined by a modified Lowry method and expressed per $10^{6}$ cells. ANG II for 48 $\mathrm{h}\left(10^{-8} \mathrm{M}\right.$ given twice) significantly stimulated total protein content in MCT cells. This effect was attenuated when $30 \mu \mathrm{g} / \mathrm{ml}$ neutralizing anti-TGF- $\beta$ antibody ( $\alpha$ TGF $\beta$ Ab) was included in the incubation medium. The antibody alone had no significant effect on baseline protein content in cells grown in control medium. $n=6 ;{ }^{*} P<0.05$ vs. unstimulated control cells.
Table II. ${ }^{3}$ H]Leucine Incorporation

into De Novo Synthesized Proteins

\begin{tabular}{lc}
\hline & $\begin{array}{c}\text { Leucine } \\
\text { incorporation }\end{array}$ \\
\hline & $\%$ \\
Controls & $98 \pm 14$ \\
$10^{-8} \mathrm{M}$ ANG II & $180 \pm 30^{*}$ \\
$10^{-8} \mathrm{M}$ ANG II $+30 \mu \mathrm{g} / \mathrm{ml}$ anti-TGF- $\beta$ antibody & $112 \pm 6$ \\
$1 \mathrm{ng} / \mathrm{ml}$ recombinant human TGF- $\beta_{1}$ & $173 \pm 16^{*}$ \\
\hline
\end{tabular}

Percentage of $\left[{ }^{3} \mathrm{H}\right]$ leucine incorporation into unstimulated control cells. Values are mean \pm SEM; $n=8 ;{ }^{*} P<0.01$ vs. controls.

was blocked by cotreatment with the anti-TGF- $\beta$ antibody ( Table III).

Bioassay for $T G F-\beta$. We next measured bioactive TGF- $\beta$ in cell culture supernatants from MCT cells incubated with ANG II. TGF- $\beta$ activity was measured using the mink lung epithelial cell assay. This bioassay is well characterized and depends on the exquisite inhibition of proliferation of CCL-64 cells in the presence of TGF- $\beta(22,23)$. We calculated $\left[{ }^{3} \mathrm{H}\right]$ thymidine incorporation into mink lung cells as percent of control values whereas control conditions refer to medium obtained from MCT cells incubated in control medium without ANG II. CCL-64 cells grown directly in fresh DME without serum exhibited an increase in proliferation compared with cells incubated with supernatants from MCT cells grown without ANG II (DME without serum: $131.5 \pm 7.0 \%$ of control; MCT cell supernatant without ANG II, 48 h: $100 \pm 16 \%$ of control, $n=6$, $P<0.01$ ). This finding suggests that unstimulated MCT cells release basal concentrations of antimitogenic substances, which may include bioactive TGF- $\beta$, that are sufficient to inhibit the proliferation of CCL-64 cells. Direct addition of $10^{-8}$ M ANG II to CCL-64 cells had no significant effect on proliferation compared with cells incubated in DME without serum (DME plus $10^{-8} \mathrm{M}$ ANG II for $24 \mathrm{~h}: 123.4 \pm 38.6 \%$ of control, $n$ $=9$, not significant vs. cells grown in DME without ANG II). In contrast, incubation of CCL-64 cells with conditioned supernatant derived from MCT cells grown in the presence of various concentrations of ANG II $\left(10^{-9}-10^{-6} \mathrm{M}\right)$ for $48 \mathrm{~h}$ significantly inhibited mitogenesis when compared with cells grown in supernatant from MCT cells without the peptide (Fig. $3 \mathrm{~A}$ ). Furthermore, direct addition of $10 \mathrm{pg} / \mathrm{ml}$ recombinant TGF- $\beta_{1}$ to CCL-64 cells also inhibited proliferation by $30 \%$

Table III. $\left[{ }^{3} \mathrm{H}\right]$ Uridine Incorporation into Total RNA

\begin{tabular}{ll}
\hline & $\begin{array}{c}\text { Uridine } \\
\text { incorporation }\end{array}$ \\
\hline & $\times 10^{4} \mathrm{cpm} /$ well \\
Controls & $2.50 \pm 0.31$ \\
$10^{-8} \mathrm{M}$ ANG II & $6.00 \pm 0.88^{*}$ \\
Controls $+30 \mu \mathrm{g} / \mathrm{ml}$ anti-TGF- $\beta$ antibody & $2.21 \pm 0.22$ \\
$10^{-8} \mathrm{M}$ ANG II $+30 \mu \mathrm{g} / \mathrm{ml}$ anti-TGF- $\beta$ antibody & $2.86 \pm 0.43$ \\
$1 \mathrm{ng} / \mathrm{ml}$ recombinant human TGF- $\beta_{1}$ & $7.67 \pm 1.00^{*}$ \\
\hline
\end{tabular}

Values are mean $\pm \mathrm{SEM} ; n=6 ;{ }^{*} P<0.01$ vs. controls. 


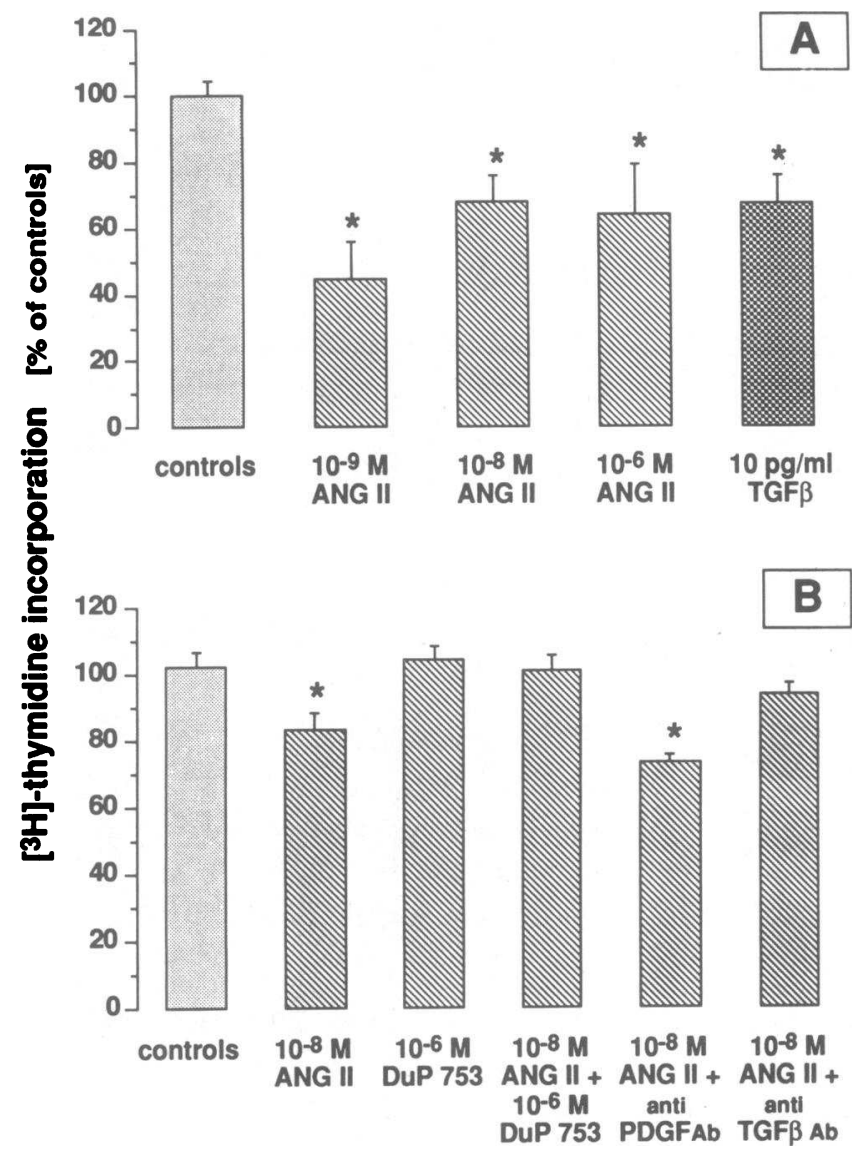

Figure 3. ( $A$ and $B$ ) Bioassay for TGF- $\beta$ using mink lung epithelial cells (CCL-64). Quiescent CCL-64 cells were incubated for $24 \mathrm{~h}$ with supernatants derived from MCT cells stimulated for $48 \mathrm{~h}$ with mediators. CCL-64 cells were pulsed for the last $6 \mathrm{~h}$ with $\left[{ }^{3} \mathrm{H}\right]$ thymidine and relative incorporation rates were calculated assigning a relative value of $100 \%$ for $\left[{ }^{3} \mathrm{H}\right]$ thymidine incorporation into DNA of CCL-64 cells incubated in supernatants from MCT cells that were grown in control medium (controls). $(A)$ CCL-64 cells grown in supernatants from MCT cells stimulated with different concentrations of ANG II $\left(10^{-9}-10^{-6} \mathrm{M}\right)$ were significantly growth suppressed. Direct addition of $10 \mathrm{pg} / \mathrm{ml}$ recombinant TGF- $\beta_{1}$ induced a similar decrease in proliferation of CCL-64 cells. $(B)$ Suppression of CCL-64 cell proliferation by the supernatant from MCT cells incubated with $10^{-8} \mathrm{M}$ ANG II was attenuated when MCT cells were coincubated with either $10^{-6}$ $\mathrm{M}$ of the $\mathrm{AT}_{1}$ receptor antagonist DuP 753 (Iosartan) or $30 \mu \mathrm{g} / \mathrm{ml}$ neutralizing anti-TGF- $\beta$ antibody (Anti-TGF $\beta$ Ab). Incubation of MCT cells with $10^{-6} \mathrm{M}$ Dup 753 alone had no significant effect on proliferation of CCL-64 cells. Moreover, $100 \mu \mathrm{g} / \mathrm{ml}$ of a neutralizing anti-PDGF B antibody (anti-PDGF Ab) failed to abolish the inhibition of $\left[{ }^{3} \mathrm{H}\right]$ thymidine incorporation into CCL-64 cells grown in supernatants derived from ANG II-stimulated MCT cells.

(Fig. $3 A$ ). Incubation of mink epithelial cells with $30 \mathrm{pg} / \mathrm{ml}$ recombinant TGF- $\beta_{1}$ also significantly inhibited mitogenesis of these cells ( $66 \pm 17.5 \%$ of control; $n=4, P<0.05$ vs. control). As shown in Fig. $3 \mathrm{~B}$, the ability of supernatants from MCT cells treated with $10^{-8} \mathrm{M}$ ANG II for $48 \mathrm{~h}$ to inhibit proliferation of CCL-64 cells was abolished when MCT cells were incubated with ANG II in the presence of $10^{-6} \mathrm{M}$ of the

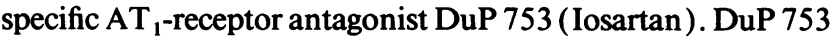
alone did not stimulate release of bioactive TGF- $\beta$ from MCT cells. Furthermore, the inhibition of $\left[{ }^{3} \mathrm{H}\right]$ thymidine incorpora- tion into mink epithelial cells grown in supernatants from ANG II-stimulated MCT cells was blocked when $30 \mu \mathrm{g} / \mathrm{ml}$ neutralizing anti-TGF- $\beta$ antibody was added, but not when $100 \mu \mathrm{g} / \mathrm{ml}$ of a goat anti-human platelet-derived growth factor (PDGF)-B neutralizing antibody was included in the medium (Fig. $3 B$ ).

Semi-quantitative cDNA amplification and Northern blots for $T G F-\beta$. To assess transcript levels for TGF- $\beta_{1}$ in MCT cells, we initially used semi-quantitative cDNA amplification to obtain information on the time-course of stimulation by ANG II. We have previously demonstrated the reliability of this method for transcript evaluation (29-31). As shown in Fig. 4, incubation of quiescent MCT cells with daily (every $24 \mathrm{~h}$ ) doses of $10^{-8} \mathrm{M}$ ANG II resulted after 24 and $48 \mathrm{~h}$ in a doubling of TGF- $\beta_{1}$ transcripts. There was no associated change in GAPDH transcripts, suggesting that the effect of ANG II was not generalized. Although the size of the reaction products for murine TGF- $\beta_{1}$ and GAPDH were as predicted by their sequences, the identity of the amplification products was also confirmed by Southern hybridization to specific internal oligonucleotides (data not shown). Furthermore, amplification of a control plasmid containing the murine TGF- $\beta_{1}$ cDNA with the TGF- $\beta_{1}$ primers resulted in a product of the same expected size (data not shown). Northern blot analysis of $20 \mu \mathrm{g}$ total RNA from MCT cells stimulated for $48 \mathrm{~h}$ with $10^{-8} \mathrm{M}$ ANG II showed a 1.93-fold increase in relative mRNA levels for TGF$\beta_{1}$ (Fig. 5). To further test for the specificity of this response, a syngeneic mouse mesangial cell line (MMC) was also treated with ANG II. In a similar protocol, we have previously shown that ANG II, in contrast to MCT cells, induces in these cells a modest degree of proliferation (24). Fig. 5 demonstrates that ANG II treatment of MMCs resulted in a decrease (rather than an increase ) in TGF- $\beta_{1}$ mRNA expression, to a level which was 0.75 times the relative mRNA level in control MMCs.

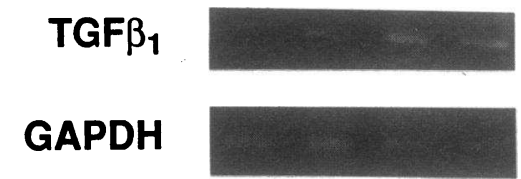

Figure 4. Semi-quantitative cDNA amplification for TGF- $\beta_{1}$ transcripts. Quiescent MCT cells were incubated for varied time periods with

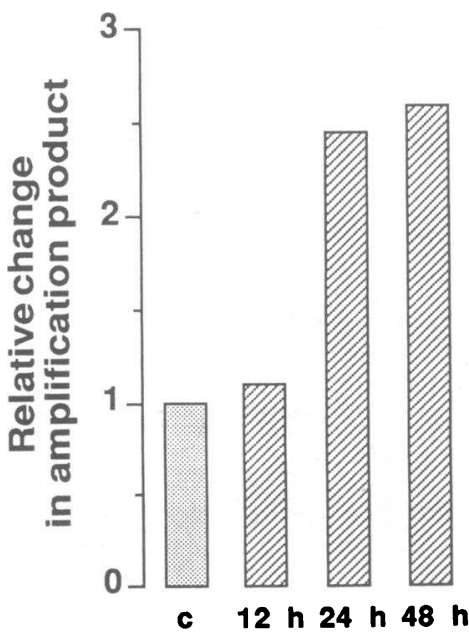
$10^{-8} \mathrm{M}$ ANG II. Total RNA was harvested at the end of the experiments, reverse transcribed, and the cDNA was amplified as described in Materials and Methods. Expression of TGF- $\beta_{1}$ transcripts more than doubled after $24 \mathrm{~h}$ of ANG II incubation. The expression of GAPDH was not significantly influenced by ANG II. The insert shows the amplification product of one representative experiment, and the graph represents the mean of three independent experiments with separate treatment, reverse transcription, and amplification reactions. 


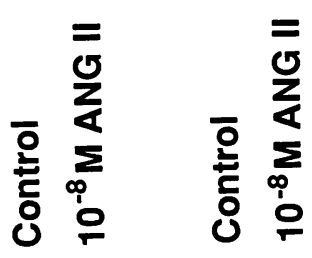

TGF- $\beta_{1}$
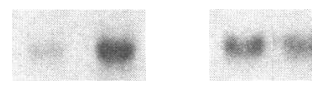

$2.5 \mathrm{~kb}$

GAPDH
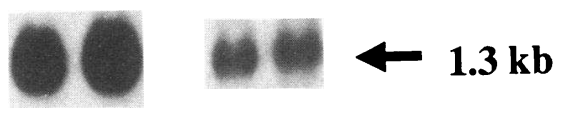

\section{$M C T \quad M M C$}

Figure 5. Northern blot analysis of RNA isolated from MCT cells or a syngeneic murine mesangial cell line (MMC) grown for $24 \mathrm{~h}$ in the presence of $10^{-8} \mathrm{M}$ ANG II or control medium. Expression of TGF$\beta_{1}$ transcripts increased in MCT cells stimulated with ANG II whereas treatment of MMCs with ANG II slightly decreased mRNA levels for TGF- $\beta_{1}$. The blots were stripped and rehybridized with a cDNA probe for the housekeeping gene GAPDH to adjust for small variations in RNA loading and transfer to the filter.

\section{Discussion}

We and others have previously demonstrated that the vasoconstrictive peptide ANG II induces cellular hypertrophy of cultured proximal tubular cells (12-16). Cellular hypertrophy was defined in these studies as an increase in cell size, protein and RNA synthesis, as well as total protein content in the absence of cellular proliferation (12-15). Moreover, DNA synthesis was inhibited after ANG II treatment of MCT and LLC-PK cells $(12,15)$. These hypertrophogenic effects of ANG II in MCT cells depend on signal transduction through the AT 1 receptor, use a pertussis toxin-sensitive G-protein, and cause a decrease in intracellular cAMP $(12,13)$. Interestingly, cellular enlargement of MCT cells by ANG II was accompanied by increased transcription and synthesis of collagen type IV (14). Since it has been previously shown that TGF- $\beta$ inhibits proliferation of various cell types and stimulates collagen synthesis (33-35), we speculated whether the growth effects of ANG II in proximal tubular cells were mediated by autocrine TGF- $\beta$ production. TGF- $\beta$ is a ubiquitous growth factor that functions in an autocrine or paracrine fashion to exert a multiplicity of effects on cells (33-35). Furthermore, Fine et al. (8) were the first to demonstrate that addition of exogenous TGF- $\beta$ inhibited the proliferation that was induced by insulin and hydrocortisone in BSC-1 cells (a tubular cell line from African green monkey kidneys) and transformed this mitogenic stimulus into cellular hypertrophy. In addition, our group has previously shown that treatment with TGF- $\beta_{1}$ inhibits proliferation (10) and induces cellular hypertrophy in MCT cells (33, and Ziyadeh et al., unpublished observations). The present study was therefore undertaken to evaluate the hypothesis that the peculiar growth effects of ANG II in MCT cells are mediated by endogenous production of TGF- $\beta$. Anti-TGF- $\beta$ antibody, but not control IgG, abolished the ANG II-mediated inhibition of proliferation as well as the induction of cellular hypertrophy as assessed by de novo protein and total RNA synthesis and total protein content. MCT cells stimulated with ANG II produced bioactive TGF- $\beta$ as measured by the well-characterized bioassay using inhibition of proliferation of CCL-64 cells. The bioactivation of TGF- $\beta$ by ANG II was mediated through stimulation of $\mathrm{AT}_{1}$ receptors since it was blocked by coincubation with the nonpeptide receptor antagonist DuP 753 (Iosartan). This is in accordance with earlier studies demonstrating that the ANG II-stimulated hypertrophy in MCT and LLC-PK cells is transduced through ANG II receptors of the $\mathrm{AT}_{1}$ class $(14,15)$.

MCT cells grown in the absence of ANG II in DME (containing $450 \mathrm{mg} / \mathrm{dl}$ glucose) produced active basal levels of TGF- $\beta$ that were further stimulated after treatment with ANG II. We have previously demonstrated that switching the culture medium from low glucose $(100 \mathrm{mg} / \mathrm{dl})$ to high glucose $(450$ $\mathrm{mg} / \mathrm{dl}$ ) inhibits MCT cell proliferation (9), an action that is mediated by bioactivation of autocrine TGF- $\beta$ (10). In a series of previous experiments, we evaluated the influence of glucose content of the medium on ANG II-mediated hypertrophy in cultured proximal tubular cells (14). Interestingly, ANG II was able to induce hypertrophy only in the presence of a high glucose concentration in the medium (14). These results suggest that either ANG II-stimulated TGF- $\beta$ production does not occur in medium with low glucose concentration or that the peptide-mediated hypertrophy requires an increase in baseline TGF- $\beta$ production that can be readily achieved in a high glucose concentration. Further studies are currently underway to test the influence of medium glucose concentration on ANG II-induced TGF- $\beta$ bioactivation in MCT cells.

A series of observations has recently established a link between ANG II action and TGF- $\beta$ expression in the kidney. For example, using immunohistochemistry, Horikoshi et al. (36) found an increase in staining for TGF- $\beta_{2}$ restricted to the juxtaglomerular apparatus and interlobular arteries in mice during severe water deprivation. Since circulating and local ANG II concentrations are presumed to be elevated in this setting and since juxtaglomerular cells express $\mathrm{AT}_{1}$ receptors (37), it appears that the increase in TGF- $\beta_{2}$ staining may be induced by ANG II. Furthermore, under conditions that result in chronic stimulation of renin production, juxtaglomerular cells undergo hypertrophy (38) and the increase in local TGF- $\beta$ synthesis could be involved in this adaptive change (37). A more direct link between ANG II and TGF- $\beta$ production was recently demonstrated by several groups in cultured vascular smooth muscle cells (VSMC; 39-41). In the presence of serum, ANG II induced cellular proliferation in VSMCs, but promoted cellular hypertrophy in the absence of serum or additional factors (39). Gibbons et al. (39) demonstrated that this bifunctional effect depended on the induction of autocrine TGF- $\beta_{1}$ production. $10^{-6} \mathrm{M}$ ANG II increased TGF- $\beta$ mRNA levels $8 \mathrm{~h}$ after stimulation in VSMCs (39). This effect was likely mediated by the protein kinase $C$ pathway since downregulation of this enzyme with phorbol ester attenuated the induction of TGF- $\beta$ transcripts by ANG II (39). Moreover, ANG II also induced significantly the production of bioactive TGF- $\beta$ in VSMCs as measured by the mink epithelial cell bioassay (39). Stouffer and Owens (40) also demonstrated in VSMCs derived from spontaneously hypertensive rats that ANG II treatment of these cells was associated with an increase in TGF- $\beta$ levels as measured by the mink epithelial cell bioassay. It has been demonstrated that ANG II induces the production of PDGF in VSMCs $(41,42)$. The parallel induction of TGF- $\beta_{1}$ may exert an antiproliferative effect on the ANG II-stimulated PDGF 
synthesis resulting in hypertrophy rather than hyperplasia in the absence of serum (39). However, it appears unlikely that this mechanism is operative in MCT cells since these cells did not express mRNA for the PDGF $B$ chain after stimulation with ANG II (12).

The increase in steady-state levels of TGF- $\beta$ mRNA in MCT cells after ANG II stimulation could be due to an increase in transcriptional activity and/or stabilization of transcripts. Regulation of TGF- $\beta$ transcription is complex; two promoters with several binding sites for the transcription factors Sp1 and NF-1 as well as a sequence typical of genes responsive to phorbol ester have been identified in the 5'-flanking region of the murine TGF- $\beta_{1}$ gene (43). We have previously demonstrated that the ANG II-induced hypertrophy in MCT cells depends, at least to some extent, on the downregulation of intracellular cAMP since agents enhancing the levels of cAMP such as forskolin or analogues of CAMP attenuated the hypertrophy (13). As a hypothesis, a decrease in activity of cAMP-dependent kinase may lead to an underphosphorylation of nuclear transcription factors which, in turn, may bind or be released from putative regulatory elements in the TGF- $\beta$ promoter. In addition, some authors have reported that ANG II also uses the phosphatidyl inositol/protein kinase $\mathrm{C}$ signal transduction pathway in proximal tubular cells (44). Thus, an activation of protein kinase $C$ may lead to an increase in TGF- $\beta$ transcription by interacting with the phorbol ester response element (45). Finally, ANG II stimulates the activity of S6 kinase in proximal tubular cells (16). S6-Kinase plays a pivotal role in translational regulation (16), and an increase in this enzyme may induce changes in TGF- $\beta$ protein concentrations.

The mechanism of TGF- $\beta$-mediated inhibition of proliferation is believed to depend on the phosphorylation of the protein product of the retinoblastoma gene ( $p R B)$, which is inhibited by TGF- $\beta(46,47)$. TGF- $\beta$-mediated under-phosphorylation of pRB arrests cells in the $G_{1}$ phase of the cell cycle (46, 47). Data by Howe et al. (48) suggest that TGF- $\beta_{1}$ decreases phosphorylation of the $\mathrm{p} 34^{\mathrm{cdc} 2}$ protein kinase that is necessary for cells to progress into the DNA replication phase of the cell cycle. This is compatible with our previous findings demonstrating that MCT cells undergoing ANG II-mediated hypertrophy are clamped in the $G_{1}$ phase (12).

Recent studies have identified TGF- $\beta$ as a major culprit in promoting glomerular sclerosis in immune-mediated models of renal injury $(49,50)$. Additionally, the progression of most renal diseases is more closely associated with morphological changes in the tubulo-interstitial environment rather than with alterations of the glomerular architecture (51-53). A sequence of events involving early compensatory tubular hypertrophy with subsequent atrophy and interstitial fibrosis has been observed in many models of chronic renal damage $(2,5)$. It is intriguing to speculate that TGF- $\beta$ may play a role in this chain of pathophysiological events leading to chronic renal failure (54). A mediator role for ANG II in this process in vivo remains to be established. However, treatment of animals after renal ablation (55) or experimentally induced aminonucleoside nephrosis (56) with converting-enzyme inhibitors has resulted in diminished deposition of tubulo-interstitial matrix. Moreover, rats infused with ANG II for $14 \mathrm{~d}$ by osmotic minipumps have revealed a mild interstitial fibrosis with increased type IV collagen deposition (57).

In summary, the cellular hypertrophy that is induced by ANG II in cultures of murine proximal tubular cells appears to be mediated by increased synthesis and bioactivation of endogenous TGF- $\beta$. A role for TGF- $\beta$ in mediating compensatory renal hypertrophy in renal diseases, which are characterized by increased activity of intrarenal ANG II, is suggested by these in vitro studies. Further studies are necessary to identify the relationship between ANG II, TGF- $\beta$, and tubulo-interstitial hypertrophy and fibrosis in established in vivo models of chronic renal injury.

\section{Acknowledgments}

The TGF- $\beta_{1}$ cDNA probe was provided by Dr. A. Singh. DuP 753 (Iosartan) was a gift from Dr. R. D. Smith. We are grateful for the continued support of Drs. Stanley Goldfarb and Eric G. Neilson.

This study was supported by grants from the Deutsche Forschungsgemeinschaft (Sta 193/2-5, Sta 193/6-1, Wo 460/2-1) and from the National Institutes of Health (DK-45191, DK-44513, DK-39565, DK07006).

\section{References}

1. Brenner, B. M. 1985 . Nephron adaptation to renal injury or ablation. Am. J. Physiol. 249:F324-F337.

2. Fine, L. G. 1986. The biology of renal hypertrophy. Kidney Int. 29:619634.

3. Wolf, G., and E. G. Neilson. 1991. Molecular mechanisms of tubulointerstitial hypertrophy and hyperplasia. Kidney Int. 39:401-420.

4. Kujubu, D. A., J. T. Norman, H. R. Herschman, and L. G. Fine. 1991. Differences in induction of TIS primary response genes in renal hypertrophy and hyperplasia suggest distinct growth-initiation processes. Am. J. Physiol. 260:F823-F827.

5. Wesson, L. G. 1989. Compensatory growth and other growth responses of the kidney. Nephron. 51:149-184.

6. Nagaike, M., S. Hirao, H. Tajima, S. Noji, S. Taniguchi, K. Matsumoto, and T. Nakamura. 1991. Renotropic functions of hepatocyte growth factor in renal regeneration after unilateral nephrectomy. J. Biol. Chem. 266:2278122784.

7. Ishibashi, K., S. Sasaki, H. Sakamoto, Y. Nakamura, T. Hata, T. Nakamura, and F. Marumo. 1992. Hepatocyte growth factor is a paracrine factor for renal epithelial cells: stimulation of DNA synthesis and $\mathrm{Na}, \mathrm{K}-\mathrm{ATPase}$ activity. Biochem. Biophys. Res. Commun. 182:960-965.

8. Fine, L. G., R. W. Holley, H. Nasri, and B. Badie-Dezfooly. 1985. BSC-1 growth inhibitor transforms a mitogenic stimulus into a hypertrophic stimulus for renal proximal tubular cells: relationship to $\mathrm{Na}^{+} / \mathrm{H}^{+}$antiport activity. Proc. Natl. Acad. Sci. USA. 82:6163-6166.

9. Ziyadeh, F. N., E. R. Snipes, M. Watanabe, R. J. Alvarez, S. Goldfarb, and T. P. Haverty. 1990. High glucose induces cell hypertrophy and stimulates collagen gene transcription in proximal tubule. Am. J. Physiol. 259:F704-F714.

10. Rocco, M. V., Y. Chen, S. Goldfarb, and F. N. Ziyadeh. 1992. Elevated glucose stimulates TGF- $\beta$ gene expression and bioactivity in proximal tubule. Kidney Int. 41:107-114.

11. Mackovic-Basic, M., L. G. Fine, J. T. Norman, E. J. Cragoe, and I. Kurtz. 1992. Stimulation of $\mathrm{Na}^{+} / \mathrm{H}^{+}$exchange is not required for induction of hypertrophy of renal cells in vitro. J. Am. Soc. Nephrol. 3:1124-1130.

12. Wolf, G., and E. G. Neilson. 1990. Angiotensin II induces cellular hypertrophy in cultured murine proximal tubular cells. Am. J. Physiol. 259:F768F777.

13. Wolf, G., P. D. Killen, and E. G. Neilson. 1991. Intracellular signalling of transcription and secretion of type IV collagen after angiotensin II-induced cellular hypertrophy in cultured proximal tubular cells. Cell Regul. 2:219-227.

14. Wolf, G., E. G. Neilson, S. Goldfarb, and F. N. Ziyadeh. 1991. The influence of glucose concentration on angiotensin II-induced hypertrophy of proximal tubular cells in culture. Biochem. Biophys. Res. Commun. 176:902909.

15. Wolf, G., G. Zahner, U. Mondorf, W. Schoeppe, and R. A. K. Stahl. 1993. Angiotensin II stimulates cellular hypertrophy of LLC-PK 1 cells through the AT, receptor. Nephrol. Dial. Transplant. 8:128-133.

16. Harris, R. C. 1992. Regulation of S6 kinase activity in renal proximal tubule. Am. J. Physiol. 263:F127-F134.

17. Haverty, T. P., C. J. Kelly, W. H. Hines, P. S. Amenta, M. Watanabe, R. A. Harper, N. A. Kefalides, and E. G. Neilson. 1988. Characterization of a renal tubular epithelial cell line which secretes the autologous target antigen of autoimmune experimental interstitial nephritis. J. Cell Biol. 107:1359-1368. 
18. Wolf, G., and E. G. Neilson. 1992. Effects of angiotensin II on proximal tubular cells stably transfected with the c-mas oncogene. Am. J. Physiol. 263:F931-F938.

19. Moe, O. W., R. T. Miller, S. Horie, A. Cano, P. A. Preisig, and R. J. Alpern. 1991. Differential regulation of $\mathrm{Na} / \mathrm{H}$ antiporter by acid in renal epithelial cells and fibroblasts. J. Clin. Invest. 88:1703-1708.

20. Levi, M., P. Wilson, and J. Cooper. 1991. Membrane cholesterol is decreased and fluidity is increased in renal MCT cells adapted to a low phosphate medium. J. Am. Soc. Nephrol. 2:775a. (Abstr.)

21. Ziyadeh, F. N., D. A. Simmons, E. R. Snipes, and S. Goldfarb. 1991. Effect of myo-inositol on cell proliferation and collagen transcription and secretion in proximal tubule cells cultured in elevated glucose. J. Am. Soc. Nephrol. 1:1220-1229.

22. Meager, A. 1991. Assays for transforming growth factor $\beta$. J. Immunol. Methods. 141:1-14.

23. Danielpour, D., D. Dart, K. C. Flanders, A. B. Roberts, and M. B. Sporn 1989. Immunodetection and quantitation of the two forms of transforming growth factor-beta (TGF- $\beta_{1}$ and TGF- $\beta_{2}$ ) secreted by cells in culture. $J$. Cell. Physiol. 138:79-86.

24. Wolf, G., U. Haberstroh, and E. G. Neilson. 1992. Angiotensin II stimulates the proliferation and biosynthesis of type I collagen in cultured murine mesangial cells. Am. J. Pathol. 140:95-107.

25. Chomczynski, P., and N. Sacchi. 1987. Single-step method of RNA isolation by acid guanidinium thiocyanate-phenol-chloroform extraction. Anal. Biochem. 162:156-159.

26. Feinberg, A. P., and B. Vogelstein. 1983. A technique for radiolabeling DNA restriction endonuclease fragments to high specific activity. Anal. Biochem. 132:6-13.

27. Derynck, R., J. A. Jarret, E. Y. Chen, D. H. Eaton, J. R. Bell, R. K Assoian, A. B. Roberts, M. B. Sporn, and D. V. Goeddel. 1985. Human transforming growth factor- $\beta$ complementary DNA sequence and expression in normal and transformed cells. Nature (Lond.). 316:701-705.

28. Tso, J. Y., X. H. Sun, K. S. Reece, and R. Wu. 1985. Isolation and characterization of rat and human glyceraldehyde-3-phosphate dehydrogenase cDNAs: genomic complexity and molecular evolution of the gene. Nucleic Acids Res. 13:2485-2502.

29. Wolf, G., G. S. Kuncio, M. J. Sun, and E. G. Neilson. 1991. Expression of homeobox genes in a proximal tubular cell line derived from adult mice. Kidney Int. 39:1027-1033.

30. Heeger, P., G. Wolf, C. Meyers, M. J. Sun, S. C. O’Farrell, A. M. Krensky, and E. G. Neilson. 1992. Isolation and characterization of cDNA from renal tubular epithelium encoding murine Rantes. Kidney Int. 41:220-225.

31. Rocco, M. V., E. G. Neilson, J. R. Hoyer, and F. N. Ziyadeh. 1992. Attenuated expression of epithelial cell adhesion molecules in murine polycystic kidney disease. Am. J. Physiol. 262:F679-F686.

32. Derynck, R., J. A. Jarrett, E. Y. Chen, and D. V. Goeddel. 1986. The murine transforming growth factor- $\beta$ precursor. J. Biol. Chem. 261:4377-4379.

33. Rocco, M. V., and F. N. Ziyadeh. 1991. Transforming growth factor-beta: an update on systemic and renal actions. In Hormones, Autacoids, and the Kidney. S. Goldfarb and F. N. Ziyadeh, editors. Contemporary Issues in Nephrology 23. Churchill Livingstone, New York. 391-410.

34. Sporn, M. B., and A. B. Roberts. 1990 . TGF- $\beta$ : problems and prospects. Cell Regul. 1:875-882.

35. Border, W. A., and E. Ruoslahti. 1992. Transforming growth factor- $\beta$ in disease: the dark side of tissue repair. J. Clin. Invest. 90:1-7.

36. Horikoshi, S., B. K. McCune, P. E. Ray, J. B. Kopp, M. B. Sporn, and P. E. Klotman. 1991. Water deprivation stimulates transforming growth factor- $\beta_{2}$ accumulation in the juxtaglomerular apparatus of mouse kidney. J. Clin. Invest. 00:2117-2122.

37. Kakinuma, Y., T. Inagami, A. Fogo, and I. Ichikawa. 1992. In situ hybridization studies of the intrarenal localization of angiotensin II type 1 receptors (AT, 1 . J. Am. Soc. Nephrol. 3:496a. (Abstr.)
38. Gomez, R. A., K. S. Lynch, R. L. Chevalier, A. D. Everett, D. W. Johns, N. Wilfong, M. J. Peach, and R. M. Carey. 1988. Renin and angiotensinogen gene expression and intrarenal renin distribution during ACE inhibition. Am. J. Physiol. 254:F900-F906.

39. Gibbons, G. H., Pratt, R. E., and V. J. Dzau. 1992. Vascular smooth muscle cell hypertrophy vs. hyperplasia. Autocrine transforming growth factor- $\beta_{1}$ expression determines growth response to angiotensin II. J. Clin. Invest. 90:456461.

40. Stouffer, G. A., and G. K. Owens. 1992. Angiotensin II-induced mitogenesis of spontaneously hypertensive rat-derived cultured smooth muscle cells is dependent on autocrine production of transforming growth factor- $\beta$. Circ. Res. 70:820-828.

41. Hahn, A. W. A., T. J. Resink, J. Bernhardt, F. Ferracin, and F. R. Buhler 1991. Stimulation of autocrine platelet-derived growth factor AA-homodimer and transforming growth factor $\beta$ in vascular smooth muscle cells. Biochem. Biophys. Res. Commun. 178:1451-1458.

42. Naftilian, A. J., R. E. Pratt, and V. J. Dzau. 1989. Induction of plateletderived growth factor A-chain and $c$-myc gene expression by angiotensin II in cultured rat vascular smooth muscle cells. J. Clin. Invest. 83:1419-1424.

43. Geiser, A. G., S. J. Kim, A. B. Roberts, and M. B. Sporn. 1991. Characterization of the mouse transforming growth factor- $\beta_{1}$ promoter and activation by the Ha-ras oncogene. Mol. Cell. Biol. 11:84-92.

44. Liu, F. Y., and M. G. Cogan. 1990. Role of protein kinase C in proxima bicarbonate absorption and angiotensin signaling. Am. J. Physiol. 258:F927F933.

45. Moses, H. L., E. Y. Yang, and J. A. Pietenpol. 1990. TGF- $\beta$ stimulation and inhibition of cell proliferation: new mechanistic insights. Cell. 63:245-247.

46. Laiho, M., J. A. DeCapiro, J. W. Ludlow, D. M. Livingstone, and J. Massague. 1990. Growth inhibition by TGF- $\beta$ linked to suppression of retinoblastoma protein phosphorylation. Cell. 62:175-185.

47. Roberts, A. B., S. J. Kim, and M. B. Sporn. 1991. Is there a common pathway mediating growth inhibition by TGF- $\beta$ and the retinoblastoma gene product? Cancer Cell. 3:19-21.

48. Howe, P. H., G. Draetta, and E. B. Leof. 1991. Transforming growth factor $\beta_{1}$ inhibition of $\mathrm{p} 34^{\mathrm{dec}}$ phosphorylation and histone $\mathrm{H} 1$ kinase activity is associated with G1 /S-phase growth arrest. Mol. Cell. Biol. 11:1185-1194.

49. Border, W. A., S. Okuda, L. R. Languimo, M. B. Sporn, and E. Ruoslahti. 1990. Suppression of experimental glomerulonephritis by antiserum against transforming growth factor $\beta_{1}$. Nature (Lond.). 346:371-374.

50. Okuda, S., L. R. Languino, E. Ruoslahti, and W. A. Border. 1990. Elevated expression of transforming growth factor- $\beta$ and proteoglycan production in experimental glomerulonephritis. Possible role in expansion of the mesangial extracellular matrix. J. Clin. Invest. 86:453-462.

51. Nath, K. A. 1992. Tubulointerstitial changes as a major determinant in the progression of renal damage. Am. J. Kidney Dis. 20:1-17.

52. Neilson, E. G. 1989. Pathogenesis and therapy of interstitial nephritis Kidney Int. 35:1257-1270.

53. Ziyadeh, F. N., and S. Goldfarb. 1991. The renal tubulointerstitium in diabetes mellitus. Kidney Int. 39:464-475.

54. Sharma, K., and F. N. Ziyadeh. 1993. The transforming growth factor- $\beta$ system and the kidney. Seminars Nephrol. 13:116-128.

55. Norman, J. T., C. Gallego, D. A. Bridgeman, A. Fogo, and L. G. Fine 1992. Enalapril ameliorates interstitial fibrosis in the remnant kidney of the rat. $J$ Am. Soc. Nephrol. 3:746a. (Abstr.)

56. Daimond, J. R., and S. Anderson. 1990. Irreversible tubulointerstitial damage associated with chronic aminonucleoside nephrosis. Amelioration by angiotensin I converting enzyme inhibition. Am. J. Pathol. 137:1323-1332.

57. Johnson, R. J., C. E. Alpers, A. Yoshimura, D. Lombardi, P. Pritzl, J. Floege, and S. M. Schwartz. 1992. Renal injury from angiotensin II-mediated hypertension. Hypertension. 19:464-474. 